\title{
Selvskading og personlighetsforstyrrelser
}

\author{
Sammendrag \\ Bakgrunn. Klinisk erfaring og nyere \\ forskning tilsier at selvskading med og \\ uten suicidal intensjon hos pasienter \\ med personlighetsforstyrrelser bør \\ forstås og behandles forskjellig. For- \\ målet med artikkelen er å gi en over- \\ sikt over selvskading uten suicidal \\ intensjon ved personlighetsforstyrrel- \\ ser.
}

\section{Materiale og metode. Artikkelen er basert på ikke-systematiske litteratur- søk i databasene PsycINFO, Medline, Clinical Evidence og Cochrane samt egne kliniske erfaringer.}

Resultater. Selvskading hos pasienter med personlighetsforstyrrelser er forbundet med ustabile personlighetstrekk. Opp mot $70 \%$ av pasienter med ustabil personlighetsforstyrrelse har rapportert selvskading uten suicidal intensjon. Ikke-suicidal selvskading er en av risikofaktorene for suicid. Ustabil personlighetsforstyrrelse utvikles i et samvirke mellom genetisk sårbarhet og traumatiske og utrygge oppvekstforhold. Pasientene er ofte preget av intense negative emosjoner og har nedsatt evne til å regulere og holde ut med disse i mellommenneskelige sammenhenger. Selvskading kan gi kortvarig lindring av den indre smerten forbundet med dysregulering av emosjoner. Dialektisk atferdsterapi og mentaliseringsbasert behandling kan redusere forekomsten av selvskading hos pasienter med ustabil personlighetsforstyrrelse. Innleggelse i psykiatrisk avdeling bør kun benyttes i kriser som ikke kan håndteres poliklinisk. Fastlegen kan representere en stabil tilknytning og fungere selvregulerende.

Fortolkning. Ikke-suicidal selvskading hos pasienter med personlighetsforstyrrelser fortjener mer oppmerksomhet og forståelse.

\section{Øyvind Urnes}

oyvind.urnes@medisin.uio.no

Avdeling for personlighetspsykiatri Oslo universitetssykehus, Ullevål 0407 Oslo

«Nakne fingre stryker forsiktig over sår som er lukket - stivnet blod lukker revnen og skjuler dybden - nakne fingre stryker ømt over ytre sår som er indre.» (1)

En ung kvinne søkte behandling pga. selvskading, selvmordstanker og angst. Hun beskrev at hun hadde vansker «med å finne meg selv eller identiteten min». I barndommen var hun sterkt knyttet til faren som imidlertid var aggressiv og slo henne. Moren var deprimert og ble opplevd som fjern. Kvinnen hadde ikke greid å fullføre videregående skole tross gode evner og heller ikke vært i noe fast arbeidsforhold. Hun taklet ikke når kjærester gjorde tilnærmelser til henne. Selv om hun beskrev seg som sosial, reagerte hun fort med sinne når andre kom nær henne. Ofte drakk hun impulsivt til hun fikk blackout. Hun slet med innsovningsproblemer og ble ofte liggende gjennom hele natten uten å sove. Daglig rispet eller skar hun seg med kniv på underarmene når hun følte seg stresset. Hun ble utredet og tilfredsstilte kriterier for både ustabil og paranoid personlighetsforstyrrelse, men også tilbakevendende alvorlige depresjoner, panikklidelse, somatiseringslidelse og alkoholmisbruk. Hun møtte uregelmessig til et psykoterapeutisk dagbehandlingsprogram, og etter ca. ett år hvor hun var mer regelmessig til stede i poliklinisk gruppepsykoterapi og mer tilknyttet de andre pasientene og terapeutene, ble selvskadingen gradvis sjeldnere og mindre alvorlig.

Denne kliniske kasuistikken er typisk for pasientgruppen med ustabil personlighetsforstyrrelse og selvskading. Pasienten brukte selvskading for å regulere og lindre opplevelse av stress. Vi som arbeider med pasienter med personlighetsforstyrrelser, møter nesten daglig selvskading og suicidalitet og må utrede denne problematikken hos alle pasientene. Når er det selvmordsfare når en pasient skader seg selv? Hvordan er det å bli forstått som suicidal når man skader seg for å håndtere indre smerte (2)? Dette er viktige spørsmål som klinikere står overfor.

I denne artikkelen defineres selvskading som handlinger en person gjør for skade seg selv, men uten suicidal hensikt (non-suicidal self-injury) $(3,4)$. Vanlige former for selvskading er kutting, risping, stikking med nåler, brenning og hodebanking. Den som selvskader ønsker å fortsette livet på en mindre smertefull måte, mens den som gjør selvmordsforsøk ser på selvmordet som den endelige utveien fra et smertefullt liv. En og samme pasient kan veksle mellom å selvskade og gjøre selvmordsforsøk avhengig av psykisk tilstand og av livssituasjonen (5). Nock og medarbeidere fant at $70 \%$ av ungdommer innlagt $\mathrm{i}$ en psykiatrisk avdeling som rapporterte selvskading det siste året, hadde gjort et selvmordsforsøk tidligere (6). Av og til kan det være en glidende overgang, som når selvskadingen er så alvorlig at den kan ha dødelig utfall selv om pasienten ikke har bevisst intensjon om å dø. Ofte har pasienter med alvorlige personlighetsforstyrrelser ikke full erkjennelse om egne motiver, særlig i situasjoner der de er stresset (7). I slike situasjoner må faren for selvmord stå i forgrunnen for behandlerne og tiltakene rettes inn for å trygge og stabilisere pasienten. Mehlum \& Jensen har tidligere gitt en oversikt i Tidsskriftet over behandling av suicidal atferd ved ustabil personlighetsforstyrrelse (8). Jeg vil her avgrense meg til selvskading hos pasienter med personlighetsforstyrrelser hvor selvskadingen ofte har en selvregulerende funksjon, men med alvorlige omkostninger for pasienten $i$ form av skade på kroppen, ofte skamfølelse og kompliserende konsekvenser for deres mellommenneskelige fungering og forholdet til familien og omverdenen generelt (ramme 1).

\section{Materiale og metode}

Grunnlaget for artikkelen er ikke-systematiske søk i databasene PsycINFO, Medline, Clinical Evidence og Cochrane samt egne kliniske erfaringer gjennom 30 år med selv-

\section{Hovedbudskap}

- Selvskading uten suicidal intensjon bør skilles fra suicidal atferd

- Dysregulering av emosjoner er et av de viktigste kjennetegnene ved emosjonelt ustabil personlighetsforstyrrelse

- Selvskading kan virke emosjonsregulerende

- Selvskading kan behandles med dialektisk atferdsterapi eller mentaliseringsbasert behandling 
skadende pasienter med personlighetsforstyrrelser.

\section{Forekomst}

Personlighetsforstyrrelser forekommer i overkant av $10 \%$ av befolkningen $(9,10)$ og defineres som vedvarende og uhensiktsmessige mønstre innenfor minst to av de følgende områdene: kognisjon (måter å oppfatte og forstå seg selv, andre og hendelser på), emosjonalitet (omfang, intensitet, labilitet og hensiktsmessigheten av følelsesreaksjonene), problemer med mellommenneskelig fungering og impulskontroll (11). De fleste av de ti spesifikke personlighetsforstyrrelsene forekommer i $0,5-1,5 \%$ av befolkningen. Forekomsten av ustabil personlighetsforstyrrelse er ca. $1 \%$. Personlighetsforstyrrelser forekommer trolig hos ca. $50 \%$ av pasienter som søker behandling på distriktspsykiatriske sentre i Norge (12). Av alle som søker behandling på distriktspsykiatriske sentre, har ca. $20 \%$ engstelig/unnvikende personlighetsforstyrrelse og ca. $10 \%$ ustabil personlighetsforstyrrelse. Det er bare emosjonelt ustabil personlighetsforstyrrelse som har selvskading i et av de diagnostiske kriteriene, men i dette kriteriet er selvskadingen slått sammen med suicidal atferd. Pga. betydelig komorbiditet kan pasienter med andre personlighetsforstyrrelser og andre psykiske lidelser ha ustabile personlighetstrekk, inkludert selvskading og suicidalitet, selv om de ikke får diagnosen ustabil personlighetsforstyrrelse. Mange vil også kunne ha ustabile personlighetstrekk uten å ha noen psykisk lidelse.

I en spørreskjemaundersøkelse i en vanlig skoleungdomsgruppe i Norge, der de fleste var 15-16 år, fant Ystgaard og medarbeidere en livstidsprevalens for villet egenskade (med eller uten suicidal intensjon) på $10,7 \%$, hvorav $80 \%$ ikke kom til behandling (13). Litt under halvparten rapporterte ikke suicidal intensjon. Prevalensen for villet egenskade er høyere hos ungdom enn hos voksne, men Hjelmeland \& Grøholt fant for øvrig små forskjeller i f.eks. suicidal intensjon og psykiatriske problemer sammenliknet med voksne (14). De mente at kognitiv umodenhet, noe høyere impulsivitet og manglende livserfaring kunne forklare hvorfor ungdommer oftere tyr til selvskading. Man regner også med at personlighetsforstyrrelser er vanligere hos ungdommer enn hos voksne og at dette kan forklare noe av denne forskjellen. Briere \& Gil fant at $4 \%$ av et tilfeldig utvalg av voksne personer i USA rapporterte selvskading i løpet av de siste seks månedene, men at bare et fåtall av disse representerte en risikogruppe for alvorlig psykiatrisk problematikk (15).

Alvorlig selvskading er forbundet med en rekke forskjellige mentale helseproblemer, men spesielt med emosjonelt ustabil personlighetsforstyrrelse, og er en risikofaktor for senere selvmord uansett grunnlidelsen (16). En studie fra England har vist at ca. $45 \%$ av
4391 personer som var innlagt pga. villet egenskade (med og uten suicidal intensjon) hadde personlighetsforstyrrelser (17). I et utvalg på 187 pasienter behandlet i dagavdelinger i Norge rapporterte $28 \%$ tidligere villet egenskade (18). I dette utvalget hadde $86 \%$ personlighetsforstyrrelser, hvorav $28 \%$ ustabil personlighetsforstyrrelse. Av personlighetsforstyrrelsene er ustabil personlighetsforstyrrelse og antisosial personlighetsforstyrrelse mest forbundet med selvskading og suicidalitet. James \& Taylor fant imidlertid at ustabile personlighetstrekk medierte det meste av sammenhengen mellom antisosiale personlighetstrekk og selvskading og suicidalitet hos kvinner i et studentutvalg (19). I et utvalg bestående av 290 døgninnlagte pasienter med ustabil personlighetsforstyrrelse rapporterte over $70 \%$ multiple selvskadingsepisoder (uten suicidal intensjon) ved behandlingsstart, mot $20 \%$ i en sammenlikningsgruppe av pasienter med andre personlighetsforstyrrelser (20). Selvskadingen startet svært tidlig i dette kliniske utvalget. $30 \%$ av pasientene med ustabil personlighetsforstyrrelse rapporterte selvskading før de var 12 år gamle og $30 \%$ startet i ungdomstiden (21). Det ser derfor ut som om mye av selvskadingsproblematikken ved personlighetsforstyrrelser knytter seg til trekk ved ustabil personlighetsforstyrrelse, som pga. utstrakt komorbiditet også forekommer ved andre personlighetsforstyrrelser, og at forekomsten varierer med hvilke utvalg av pasienter man undersøker.

\section{Risikofaktorer}

De fleste er enige om at ustabil personlighetsforstyrrelse utvikles $i$ et samspill mellom genetiske sårbarhetsfaktorer, genetisk forankrede temperamentstrekk og traumatiske og andre uheldige oppveksterfaringer i tilknytningsrelasjoner $(22-25)$. Et temperament preget av et høyt nivå av negative affekter og lav oppmerksomhetskontroll kan forsterkes $i$ en vanskelig tilknytningsrelasjon og utgjøre noe av grunnlaget for senere dysregulering av emosjoner (26). Hovedfokus ved ustabil personlighetsforstyrrelse har vært på seksuelle overgrep og andre traumer i tilknytningsrelasjonen, men i dag er det i tillegg økt oppmerksomhet på avbrutt og uheldig emosjonell kommunikasjon mellom barn og tilknytningsperson (27). Risikofaktorer for senere selvskading generelt sammenfaller mye med de samme oppvekstfaktorene: seksuelle overgrep, mishandling, omsorgssvikt og utrygghet i tilknytningsrelasjonen (28). Det er vanskelig å fastslå betydningen av hver enkelt risikofaktor.

En større metaanalyse av studier av seksuelle overgrep har vist en relativt beskjeden sammenheng mellom seksuelt misbruk og senere selvskading når man kontrollerte for andre faktorer (29). Men seksuelt misbruk forekommer sannsynligvis ikke alene som en skadelig faktor i en tilknytningskontekst, og det er et samvirke av uheldige faktorer

\section{Ramme 1}

\author{
Elementer $\mathrm{i}$ utredningen \\ av pasienter som skader seg selv \\ Pasientens intensjoner ved selvskading \\ må alltid kartlegges \\ Suicidal intensjon krever vurdering av \\ selvmordsrisiko og tryggende tiltak \\ Man bør lytte til og respektere pasien- \\ tens forståelse av ikke-suicidal selv- \\ skading \\ Pasienter som gjentatt eller alvorlig \\ skader seg selv bør utredes i spesia- \\ listhelsetjenesten
}

\section{Ramme 2}

\section{Selvskading ved personlighetsforstyrrelser}

Gjentatt selvskading forekommer ofte hos pasienter med personlighetsforstyrrelser

Ved ustabil personlighetsforstyrrelse forekommer selvskading hos de fleste, avhengig av klinisk tilstand

Seksuelle overgrep og andre traumer i tilknytningsrelasjoner og dårlig emosjonell kommunikasjon med foreldre i barndommen er typisk for denne pasientgruppen

Intense negative følelser, nedsatt evne til å mestre følelsene og selvnedvurdering er typiske tegn

som til sammen utgjør en betydelig risiko for senere selvskading. Ekstreme oppvekstfaktorer kan sannsynligvis også gi varige nevrobiologiske forandringer. Alvorlig traumatisering i tilknytningsrelasjonen kan føre til en senkning av den sentrale serotoninerge funksjonen, som kan innvirke på regulering av aggresjon (30) eller føre til kronisk økt aktivering av stressreguleringssystemet. Da oppstår forhøyede nivåer av kortikotropinfrigjørende faktor (CRF), adrenokortikotropt hormon (ACTH) og kortisol, som i sin tur virker nevrotoksisk og kan føre til celledød i hippocampus og amygdala (31). Hos pasienter med ustabil personlighetsforstyrrelse er det funnet holdepunkter for at hyperreaktivitet av amygdala og dysfunksjon i prefrontal cortex kan forklare noe av problemene med emosjonsregulering hos disse pasientene (32). Prefrontal cortex har en regulerende funksjon på amygdala.

\section{Personlighetsfaktorer}

Hvis vi forsøker å skille ut personlighetsmessige faktorer som er forbundet med gjentatt og alvorlig selvskading, vil vi bedre kun- 
ne forstå og evaluere pasienter med henblikk på behandlingstiltak. Klonsky \& Muehlenkamp har i en gjennomgang av forskningslitteraturen kunnet identifisere tre hovedområder (33). Det første er negativ emosjonalitet. Selvskadere har oftere mer intense negative følelser enn andre pasienter. Det dreier seg om sinne, frykt/angst, tristhet, frustrasjon og ubehag. Det andre området er problemer med emosjonelle ferdigheter. Studier har vist problemer med å erkjenne, uttrykke og holde ut med emosjoner og følelser. Ofte beskriver pasientene uvirkelighetsfølelse like før de skader seg, og dette blir forstått som en distansering eller dissosiasjon fra følelsene. Det tredje hovedområdet er selvnedvurdering. Pasientene er selvkritiske og uttrykker ofte hat overfor seg selv. Selvnedvurdering henger også sammen med lav selvfølelse (ramme 2).

\section{Hvilken funksjon har selvskading?}

For å kunne forholde seg empatisk overfor pasientene er det viktig å forstå hvilken funksjon selvskading kan ha. Vi kan skille ut noen funksjoner som til dels er overlappende. I en undersøkelse av 101 innlagte kvinnelige pasienter med ustabil personlighetsforstyrrelse anga de fleste mange motiver for selvskading (34). Klonsky fant seks områder som omhandler selvskadingens funksjon da

\section{Ramme 3}

\section{Selvskadingens ulike funksjoner oppgitt av pasienter}
Lindre sterke følelser og smertefulle indre opplevelser
Gi følelse av kontroll over seg selv og skape mening
Straffe seg selv
Fjerne opplevelse av uvirkelighet
Signalisere behov for hjelp overfor omverdenen

\section{Ramme 4}

\section{Behandling av ikke-suicidal selvskading hos pasienter med ustabil personlighetsforstyrrelse \\ I kontrollerte studier har strukturert og systematisk dialektisk adferdsterapi og mentaliseringsbasert behandling ført til reduksjon av selvskading hos pasienter med ustabil personlighets- forstyrrelse \\ Medikamentell behandling har ingen plass i behandling av selvskading \\ Fastlegen kan ha en viktig stabilise- rende funksjon for pasienten}

han gikk igjennom litteraturen på dette feltet (35). Disse funksjonene er i tråd med våre kliniske erfaringer og beskrives nedenfor (ramme 3).

\section{Emosjonsregulering}

«Kniven er min beste venn,» sa en av våre kvinnelige pasienter. Hun uttrykker noe vesentlig: Selvskading er en erstatning for betydningen av en nær og empatisk relasjon. Evne til selvregulering er en funksjon som vi erverver oss i barndommen gjennom et regulerende samvær med våre tilknytningspersoner (36). Svak emosjonell regulering kan være knyttet til den forhøyede negative emosjonaliteten og reduserte affektbevisstheten som ofte preger disse pasientene. Selvskading kan gi følelse av kontroll over indre ordløse smertefulle affekttilstander og fungerer lindrende for mange (34). Pasienter kan fortelle om en følelse av å skape mening ved å kjenne smerte, se blod og erfare ytre konkrete tegn på at noe er virkelig (37). Psykoanalytikeren Peter Fonagy kaller denne psykiske tilstanden, der det er likhetstegn mellom indre og ytre virkelighet, for psykisk ekvivalens (38). Pasienten får lindret sin psykiske smerte ved å behandle den fysisk. Andre pasienter vil gjennom selvskading kunne fremkalle følelser som de ellers har vanskelig tilgang til, f.eks. sinne, men også «kick»-følelse og lystopplevelse. Andre som er plaget av tankekjør som de ikke făr stoppet, kan føle lindring gjennom selvskading. Forskningen på selvskadingens funksjon er mest basert på selvrapportering og lite på objektive studier (39).

\section{Selvstraff}

Ved intens selvnedvurdering og selvhat kan det gi en følelse av lindring å synliggjøre selvstraff gjennom selvskading. Nest etter emosjonsregulering var selvstraff den vanligste forklaringen pasienter oppga som grunn for selvskading. Pasienter med ustabil personlighetsforstyrrelse er ofte svært selvnedvurderende («jeg hater meg selv»). Det å straffe seg selv er da i tråd med selvopplevelsen.

\section{Håndtere dissosiasjon} og uvirkelighetsfølelse

Uvirkelighetsopplevelse og fjernhet vil kunne oppleves som svært plagsomt. Noen får mer virkelighetsfølelse ved å konkretisere opplevelsen gjennom selvskading. Andre vil kunne bruke selvskading for å fjerne seg fra en virkelighetsopplevelse som de ikke håndterer, f.eks. hvis det har hendt noe vanskelig i nære forhold (40).

\section{Mellommenneskelig signal}

Vanligvis holdes selvskading skjult for omverdenen. Pasienten er flau over å bekjenne selvskadingen. Men disse handlingene kan også benyttes for å påvirke omverdenen: «Nå må noen reagere», «du skulle ikke ha sagt det til meg» eller «nå må noen skjønne at jeg trenger hjelp». Denne selvskadingen er ofte mer impulsiv, og handlingen utløses i en mellommenneskelig kontekst.

\section{Antisuicidalt}

Noen pasienter rapporterte selvskading som et middel for å hindre at de handlet ut suicidale impulser eller for å stoppe suicidaltanker.

\section{Etablere selvavgrensning}

Noen pasienter med ustabil personlighetsforstyrrelse opplever at grensene mellom en selv og andre er flytende. Disse pasientene rapporterte at selvskading kunne bidra til å kjenne hvor kroppen slutter, og dermed hvor en selv slutter - igjen et tegn på psykisk ekvivalens.

\section{Behandling}

Mennesker som skader seg selv, trenger først og fremst å bli møtt med respekt, medfølelse og forståelse. De må få behandling for de fysiske konsekvensene med lokalbedøvelse ved suturering. Zanarini og medarbeidere viste i sin oppfølgingsstudie av innlagte pasienter med ustabil personlighetsforstyrrelse at den rapporterte forekomsten av multiple selvskadingsepisoder hadde falt fra $70 \%$ til $15 \%$ etter ti år (20). Majoriteten av pasientene hadde fått behandling $\mathrm{i}$ løpet av de ti årene. Men generelt er det vist at pasienter med ustabil personlighetsforstyrrelse bedrer seg over år uansett behandling. Dette gjelder spesielt impulsivitet, suicidalitet og selvskading (41). Derfor er det nødvendig å utføre randomiserte kontrollerte studier, både for å kunne påvise effekt av behandling og for å finne ut hvilken behandling som er best.

Når det gjelder psykologisk behandling som forebygging av gjentatt selvskading hos pasienter med personlighetsforstyrrelser, er det fremdeles en viss usikkerhet om hva slags behandling som har effekt, om hvilken metode som er best og om hva som virker ved de forskjellige metodene $(5,42)$. I 2006 forelå en Cochrane-oversikt over åtte randomiserte, kontrollerte studier av psykologisk behandling av pasienter med ustabil personlighetsforstyrrelse. Sju av studiene dreide seg om virkningen av dialektisk atferdsterapi (dialectical behavior therapy, DBT) og en om virkningen av mentaliseringsbasert terapi (mentalization based therapy, MBT). Forfatterne konkluderte med at dialektisk atferdsterapi på poliklinikk og mentaliseringsbasert terapi i daghospital viste reduksjon av selvskading som et av mange mål på virkningen av behandlingen (43). Det var en betydelig overvekt av kvinnelige pasienter $\mathrm{i}$ studiene, og i noen var det bare kvinner.

\section{Dialektisk atferdsterapi}

Dialektisk atferdsterapi ble opprinnelig utviklet av den amerikanske psykologen Marsha M. Linehan som behandling for kvinnelige suicidale pasienter med ustabil 
personlighetsforstyrrelse, men anvendelsesområdet er senere utvidet til generell behandling av pasienter med ustabil personlighetsforstyrrelse, rusmisbuk, andre personlighetsforstyrrelser og generelt for pasienter med psykiske lidelser der problemer med regulering av emosjoner er fremtredende (24). Dysregulering av det affektive systemet som utvikles på basis av genetisk sårbarhet og uheldig oppvekstmiljø, ses på som kjerneproblemet ved ustabil personlighetsforstyrrelse. Som vi har beskrevet, er selvskading sannsynligvis forbundet med dysregulering av emosjoner, som blir forstått som økt sensitivitet og reaktivitet, samt forlenget aktivering av emosjonene. Dialektisk atferdsterapi går ut på å bedre emosjonelle ferdigheter gjennom å forandre emosjonell sårbarhet, bedre oppmerksomhet på hva som utløser emosjoner i interpersonlige situasjoner, regulere og styre handlingstendenser ved emosjoner, nedregulere intense emosjoner og øke bevisstheten om emosjoner og virkningen av dem. Terapeuten bør ha en aksepterende og bekreftende holdning overfor pasientens smertefulle emosjonelle opplevelse og være mentalt til stede på en deltakende og ikke-dømmende måte.

I den seneste randomiserte, kontrollerte studien av dialektisk atferdsterapi som Linehan og medarbeidere har utført blant polikliniske suicidale kvinnelige pasienter med ustabil personlighetsforstyrrelse, fikk pasientene i kontrollgruppen behandling av «eksperter på behandling av vanskelige pasienter» (44). Behandlingen varte i ett år og pasientene ble fulgt opp i til sammen to år. Denne studien viste, som tidligere studier av dialektisk atferdsterapi, signifikante forskjeller i reduksjon av selvmordsforsøk i denne behandlingsgruppens favør (50\% versus $20 \%$ reduksjon etter to år). Det var ingen forskjell $\mathrm{i}$ reduksjon av selvskading uten suicidal intensjon, men begge grupper fikk signifikant redusert selvskading (mer enn $50 \%$ reduksjon av antall selvskadingsepisoder over et gitt tidsrom).

Alle tidligere studier av ustabil personlighetsforstyrrelse har imidlertid vist signifikante forskjeller i favør av dialektisk atferdsterapi, også i reduksjon av selvskading. Som konklusjon kan vi si at dialektisk atferdsterapi fungerer overbevisende i å redusere suicidalitetsproblematikken ved ustabil personlighetsforstyrrelse, har godt dokumentert effekt for å redusere selvskading, men ikke nødvendigvis bedre enn andre tilnærminger på dette siste området. I regi av Nasjonalt senter for selvmordsforskning og -forebygging er det satt i gang en randomisert, kontrollert studie som skal undersøke virkningen av dialektisk atferdsterapi hos ungdommer i alderen 13-19 år med gjentatt villet egenskade (45).

\section{Mentaliseringsbasert terapi}

Å mentalisere betyr å erkjenne emosjonelt at mentale tilstander (følelser, tanker, motiver) styrer egen og andres atferd (46). En person med ustabil personlighetsforstyrrelse antas å ha et tilknytningssystem som hyperaktiveres pga. genetiske sårbarhetsfaktorer og traumer i tilknytningsrelasjoner i oppveksten (25). Ved hyperaktivering av tilknytningssystemet nedsettes mentaliseringsevnen, noe som resulterer i problemer med å erkjenne og forstå egne og andres emosjonelle reaksjoner og motiver (47). Derved øker sjansen for at pasienten mistolker og misforstår egne og andres motiver. Mentaliseringsbasert terapi, som er utviklet av Bateman \& Fonagy, har fokus på hvordan man kan bedre mentaliseringsevnen i relasjoner her og nå $(25,48)$. Den selvskadende pasientens følelse av å være et dårlig menneske oppleves intenst smertefullt i en psykisk ekvivalenstilstand. Pasienten ikke bare føler seg ond, men tror at han/hun er ond. I en psykisk ekvivalenstilstand der mentaliseringen er brutt sammen, er pasienten overbevist om sannheten av egen forståelse, «han kom ikke fordi han hater meg», og kan ikke tenke andre alternativer. A skade seg selv $i$ en slik situasjon vil kunne oppleves lindrende fordi det er en konkret og observerbar behandling av den smertefulle indre mentale tilstanden. Mentaliseringsbasert terapi forutsetter empatisk kontakt med pasienten, nøye kartlegging av den mellommenneskelige situasjonen pasienten var i før selvskadingen startet, utforskning av kommunikasjonsproblemer og pasientens fortolkninger av den andres reaksjoner. Terapeuten forsøker å åpne opp for alternative fortolkninger. Identifisering av emosjonene og virkningen av disse er viktig, som ved dialektisk atferdsterapi. Det gjelder å hjelpe pasienten til å forstå at sosiale situasjoner er mangetydige og vanskelige å fortolke.

Dokumentasjonen av virkningen av mentaliseringsbasert terapi er knyttet til behandlingen av pasienter med ustabil personlighetsforstyrrelse $i$ et 18 måneders dagavdelingsprogram sammenliknet med «vanlig psykiatrisk behandling» (48). Det var store forskjeller i reduksjon av alvorlig selvskading $i$ de to behandlingsgruppene etter 6,12 , 18 og 36 måneders oppfølging, og gruppen som fikk mentaliseringsbasert terapi kom best ut på alle behandlingsmålene. Ved behandlingsstart rapporterte ca. $90 \%$ selvskading det siste halve året og ved to års oppfølging var tilsvarende forekomst ca. $10 \%$ i behandlingsgruppen og ca. $60 \%$ i sammenlikningsgruppen. Reduksjon av forekomsten av rapporterte selvmordsforsøk holdt seg ved åtte års oppfølging: $\mathrm{Ca} .10 \% \mathrm{i}$ behandlingsgruppen versus ca. $50 \%$ i sammenlikningsgruppen rapporterte selvmordsforsøk i løpet av de siste to årene.

\section{Andre tilnærminger}

Sannsynligvis vil andre behandlingstilnærminger enn de jeg har omtalt i denne artikkelen være virkningsfulle ved selvskading hos pasienter med personlighetsforstyrrelser, men problemet er mangel på metodisk gode studier og at man ikke har differensiert mellom selvskading og suicidalitet (49).

\section{Innleggelse}

Det er ingen sikre holdepunkter for at døgninnleggelse kan redusere suicidalitet eller selvskading. Torgersen og medarbeidere rapporterte en liten, naturalistisk, retrospektiv studie (sju av ni hadde personlighetsforstyrrelser) på virkningen av korte, planlagte innleggelser ved villet egenskade og fant tendens til at dette reduserte frekvensen av selvskading og selvmordsforsøk (50). Tanken om at pasientenes egen medvirkning og planlegging er viktig for å styrke følelsen av å ha kontroll over egen situasjon, er i tråd med selvskadingens funksjon. Akutt innleggelse av pasienter med ustabil personlighetsforstyrrelse er aktuelt hvis ikke polikliniske planlagte kriseplaner og tiltak fører frem og man vurderer at risikoen for pasienten og andre er for stor. Man bør alltid involvere pasienten i beslutningsprosessen, helst bli enig om lengden på oppholdet på forhånd, og hvis det er nødvendig å bruke tvang, overføre ansvaret tilbake til pasienten hurtigst mulig. I England foreligger nå oppdaterte empirisk baserte retningslinjer for behandling av ustabil personlighetsforstyrrelse der dette problemområdet blir behandlet i detalj (51).

\section{Medikamentell behandling}

Det er i dag ingen holdepunkter for at psykofarmakologisk behandling kan redusere selvskading ved ustabil personlighetsforstyrrelse (52).

\section{Tilnærming i allmennpraksis}

Hva kan fastlegens rolle være? Vår erfaring tyder på at fastlegen spiller en betydelig og positiv rolle for pasienter med ustabil personlighetsforstyrrelse. Fastlegen representerer ofte en stabil og ikke-dømmende, tillitsfull person som fungerer stabiliserende for pasienten og er bindeleddet mellom forskjellige behandlingsinstanser. Når fastlegen møter pasienter som gjentatt selvskader eller har utført alvorlig selvskading, bør de henvises til utredning i spesialisthelsetjenesten. Det blir viktig å lytte til pasienten, bekrefte subjektiv lidelse og ta stilling til motivet for selvskading. Omfanget av ustabil personlighetsproblematikk bør kartlegges i tillegg til andre psykiske lidelser. Selv om fastlegen ikke inngår i det systematiske psykoterapeutiske behandlingsopplegget, vil han/hun ofte representere en stabil tilknytningsfunksjon. Ofte er det dessverre slik at man ikke får til tilsvarende stabilitet i spesialisthelsetjenesten, som sannsynligvis er en nødvendig forutsetning for god behandling. Pasientens autonomi, deltakelse i og valg av egen behandling er grunnprinsipp for omsorg for og behandling av denne pasientgruppen (ramme 4).

\section{Konklusjon}

Selvskading utgjør en viktig del av problematikken hos pasienter med ustabil person- 
lighetsforstyrrelse eller ustabile personlighetstrekk. Selvskading bør ses som tegn på mangelfull evne til emosjonsregulering og mentalisering i nære relasjoner. Emosjonell regulering og mentalisering er funksjoner som utvikles i tilknytningsrelasjoner og kan sannsynligvis endres ved psykoterapeutisk behandling. Fokus for behandlingen bør være å bedre disse funksjonene. Det er kunnskapsgrunnlag for at både dialektisk adferdsterapi og mentaliseringsbasert psykoterapi reduserer omfanget av selvskading i denne pasientgruppen.

Pasienten har gitt samtykke til at artikkelen blir publisert.

Oppgitte interessekonflikter: Ingen

\section{Litteratur}

1. Jensen MJF. Gjennom ord. Sandnes: Commentum, 2007

2. Thorsen GRB. Selvskading og selvmord... ingen selvfølge. Suicidologi 2006; nr. 1:5-9.

3. Klonsky ED. Non-suicidal self-injury: an introduction. J Clin Psychol 2007; 63: 1039-43.

4. Favazza AR. The coming of age of self-mutilation. J Nerv Ment Dis 1998; 1865: 259-68.

5. Prinstein MJ. Introduction to the special section on suicide and nonsuicidal self-injury: a review of unique challenges and important directions for self-injury science. J Consult Clin Psychol 2008: 76: 1-8.

6. Nock MK, Joiner TE jr., Gordon KH et al. Non-suicidal self-injury among adolescents: diagnostic correlates and relation to suicide attempts. Psychiatry Res 2006: 144: 65-72.

7. Bateman A, Fonagy P. Mentaliseringsbasert terapi av borderline personlighetsforstyrrelse. En praktisk veileder. Oslo: Arneberg Forlag, 2007.

8. Mehlum L, Jensen Al. Suicidal atferd ved ustabil personlighetsforstyrrelse. Tidsskr Nor Lægeforen 2006; 126: 2946-9

9. Torgersen S, Kringlen E, Cramer V. The prevaence of personality disorders in a community sample. Arch Gen Psychiatry 2001; 58: 590-6.

10. Lenzenweger MF. Epidemiology of personality disorders. Psychiatr Clin North Am 2008; 31: 395-403.

11. Diagnostic and statistical manual of mental disorders DSM IV. 4. utg. Washington, D.C.: American Psychiatric Association, 1994.

12. Narud K, Mykletun A, Dahl AA. Quality of life in patients with personality disorders seen at an ordinary psychiatric outpatient clinic. BMC Psychiatry 2005; 5: 10

13. Ystgaard M, Reinholdt NP, Husby J et al. Villet egenskade blant ungdom. Tidsskr Nor Lægeforen 2003; 123: $2241-5$

14. Hjelmeland H, Grøholt B. A comparative study of young and adult deliberate self-harm patients. Crisis 2005; 26: 64-72.

15. Briere J, Gil E. Self-mutilation in clinical and general population samples: prevalence, correlates, and functions. Am J Orthopsychiatry 1998; 68 : $609-20$

16. Andover MS, Pepper CM, Ryabchenko KA et al. Self-mutilation and symptoms of depression, anxiety, and borderline personality disorder. Suicide Life Threat Behav 2005; 35: 581 -91.

17. Haw C. Hawton K. Life problems and deliberate self-harm: associations with gender, age, suicidal intent and psychiatric and personality disorder. Affect Disord 2008; 109: 139-48.

18. Wilberg T, Karterud S, Pedersen G et al. Outpatien group psychotherapy following day treatment for patients with personality disorders. J Pers Disord 2003: 17: 510-21

19. James LM, Taylor J. Associations between symptoms of borderline personality disorder, externalizing disorders, and suicide-related behaviors. J Psychopathol Behav Assess 2008; 30: 1-9.

20. Zanarini MC, Frankenburg FR, Reich DB et al. The 10-year course of physically self-destructive acts reported by borderline patients and axis II comparison subjects. Acta Psychiatr Scand 2008. 117: 177-84.

21. Zanarini MC, Frankenburg FR, Ridolfi ME et al. Reported childhood onset of self-mutilation among borderline patients. J Pers Disord 2006 20: $9-15$

22. Zanarini MC, Frankenburg FR. The essential nature of borderline psychopathology. J Pers Disord 2007; 21: 518-35

23. Livesley J. Toward a genetically-informed mode of borderline personality disorder. J Pers Disord 2008: 22: 42-71

24. Linehan MM, Bohus M, Lynch TR. Dialectical behavior therapy for pervasive emotion dysregulation. I: Gross JJ, red. Handbook of emotion regula tion. New York, NY: Guilford Press, 2007: 581-605.

25. Fonagy $P$, Bateman $A$. The development of border line personality disorder - a mentalizing model. J Pers Disord 2008; 22: 4-21.

26. Posner MI, Rothbart MK, Vizueta N et al. Attentional mechanisms of borderline personality disorder. Proc Natl Acad Sci USA 2002; 99: 16366-70.

27. Lyons-Ruth K, Dutra L, Schuder MR et al. From infant attachment disorganization to adult dissociation: relational adaptations or traumatic experiences? Psychiatr Clin North Am 2006; 29: 63-86.

28. Gratz KL. Risk factors for and functions of deliberate self-harm: an empirical and conceptual review. Clinical Psychology: Science and Practice 2003: 10: 192-205.

29. Klonsky ED, Moyer A. Childhood sexual abuse and non-suicidal self-injury: meta-analysis. $\mathrm{Br}$ J Psychiatry 2008; 192: 166-70.

30. Mann JJ. Neurobiology of suicidal behaviour. Nat Rev Neurosci 2003; 4: 819-28

31. Brambilla P, Soloff PH, Sala M et al. Anatomical MRI study of borderline personality disorder patients. Psychiatry Res 2004; 131: 125-33.

32. Herpertz SC, Dietrich TM, Wenning B et al. Evidence of abnormal amygdala functioning in bor derline personality disorder: a functional MRI study. Biol Psychiatry 2001; 50: 292-8.

33. Klonsky ED, Muehlenkamp JJ. Self-injury: a research review for the practitioner. J Clin Psychol 2007; 63: 1045-56

34. Kleindienst N, Bohus M, Ludascher $P$ et al. Motives for nonsuicidal self-injury among women with borderline personality disorder. J Nerv Ment Dis 2008; 196: 230-6.
35. Klonsky ED. The functions of deliberate self-injury: a review of the evidence. Clin Psychol Rev 2007: 27: $226-39$

36. Posner MI, Rothbart MK, Vizueta N et al. An approach to the psychobiology of personality disorders. Dev Psychopathol 2003; 15: 1093- 106.

37. Potter NN. Commodity/body sign: Borderline per sonality disorder and the signification of self-injurious behavior. Philos Psychiatr Psychol 2003; 10: $1-17$.

38. Fonagy P, Target M. Playing with reality: III. The persistence of dual psychic reality in borderline patients. Int J Psychoanal 2000; 81: 853-73.

39. Moe A. Solveigs savn: refleksjoner i etterkant av et forskningsintervju om selvskading. Tidsskr Nor Psykologforen 2007; 44: 1254-8.

40. Stiglmayr CE, Shapiro DA, Stieglitz RD et al. Experi ence of aversive tension and dissociation in female patients with borderline personality disorder - a controlled study. J Psychiatr Res 2001; 35: 111-8.

41. Zanarini MC, Frankenburg FR, Reich DB et al. The subsyndromal phenomenology of borderline personality disorder: a 10-year follow-up study. Am J Psychiatry 2007; 164: 929-35.

42. Soomro GM. Deliberate self harm land attempted suicide). Clin Evid 2005; 13: 1200-11.

43. Binks CA, Fenton M, McCarthy L et al. Psychological therapies for people with borderline personality disorder. Cochrane Database Syst Rev 2006; $\mathrm{nr}$ 1: CD005652

44. Linehan MM, Comtois KA, Murray AM et al. Twoyear randomized controlled trial and follow-up of dialectical behavior therapy vs therapy by experts for suicidal behaviors and borderline personality disorder. Arch Gen Psychiatry 2006; 63: 757-66.

45. Larsson B, Grøholt B, Mehlum L. Behandling vid upprepad självskada och suicidförsök hos tonåringar: en planerad, randomiserad och kontrollerad multicenterstudie. Suicidologi 2006; 11: 16-7.

46. Skårderud F, Sommerfeldt B. Mentalisering - et nytt teoretisk og terapeutisk begrep. Tidsskr Nor Legeforen 2008; 128: 1066-9.

47. Bartels A, Zeki S. The neural correlates of maternal and romantic love. Neuroimage 2004; 21 : $1155-66$.

48. Bateman A, Fonagy P. 8-year follow-up of patients treated for borderline personality disorder: mentalization-based treatment versus treatment as usual. Am J Psychiatry 2008; 165: 631-8.

49. Levy KN, Yeomans FE, Diamond D. Psychodynamic treatments of self-injury. J Clin Psychol 2007; 63: $1105-20$

50. Torgersen T, Løvås E, Tofte T. Korte, planlagte innleggelser ved villet egenskade. Tidsskr Nor Lægeforen 2007: 127: 1521-3.

51. National Institute for Health and Clinical Excellence. Borderline personality disorder: treatment and management. NICE clinical guideline 78. London: National Institute for Health and Clinical Excellence, 2009. www.nice.org.uk/nicemedia/pdf/ CG78FullGuideline.pdf (18.2.2009).

52. Binks CA, Fenton M, McCarthy L et al. Pharmaco logical interventions for people with borderline personality disorder. Cochrane Database Syst Rev 2006; nr 1: CD005653.

Manuskriptet ble mottatt 15.8. 2008 og godkjent 2.3. 2009. Medisinsk redaktør Siri Lunde. 